\begin{tabular}{c} 
Volume and Issues Obtainable at Center for Sustainability Research and Consultancy \\
Sustainable Business and Society in Emerging Economies \\
ISSN: 2708-2504 ISSN (E) 2708-2172 \\
Volume 1: No. 2, December2019 \\
ᄃSRᄃ \\
Journal homepage: www.publishing.globalcsrc.org/sbsee \\
\hline
\end{tabular}

\title{
SMEs Intention towards Use and Adoption of Digital Financial Services
}

\section{${ }^{1}$ Muhammad Shahbaz Khan, ${ }^{2}$ Sulaman Hafeez Siddiqui}

${ }^{1}$ The Islamia University of Bahawalpur Pakistan, muhammadshahbazkhan7@gmail.com

2 The Islamia University of Bahawalpur Pakistan, sulman.siddiqui@iub.edu.pk

\begin{tabular}{l}
\multicolumn{1}{c}{ ARTICLE DETAILS } \\
\hline History \\
Revised format: November 2019 \\
Available Online: December 2019 \\
Keywords \\
Subjective Norms, Perceived \\
Behavior Control, Intention \\
Towards Use And Adoption of \\
Digital Financial Services
\end{tabular}

JEL Classification:

C91, C99, G23, G29

\section{ABSTRACT}

The purpose of this study is to analyses the SMEs owners and managers intention towards use and adoption of digital financial services in South Punjab, Pakistsan. SMEs are considered key contributors to economic activity, as a key-source of employment, growth, and invention. SMEs perform significant role in the system of national financial regulation all over the world, Jobs creation, and contributing to modernization in the financial regulation are significant exertions to achieve ecological sustainability and more growth in access to finance. Access to finance in emerging countries is one of core issue in development of SME sector as well as obstacle in economic growth. Microfinance institutions are considered a good manifesto to enhance access to inclusive finance as well as stress-free access to finance and financial literacy for SMEs to support economic growth but in Pakistan, to obtain these finances not easy for SMEs sectors. SMEs are unfortunately still struggling due to lack of inclusive finance and financial literacy. Recently financial institution introduced digital financial services at micro level that provide access to financial services to each and every citizen in the country without any restriction. To accomplish the purpose of the research, the data was acquired from the SMEs owners and mangers with a sample of 232 chosen randomly of South Punjab, Pakistan. In this research study, merged two best theories; the theory of planned behavior and technology acceptance model was used to describe their behavior. Multiple statistical tests run to check the normality by using Shapiro-Wilk test, reliability and multicollinearity of the data to test the assumptions of regression and correlation. Finally, the results of this intended study revealed that there is a moderate significant but positive relationship between the SMEs owners and managers intention towards use and adoption of digital financial services. The Government of Pakistan should create finance related awareness program, training, technical institution and make a rules and regulation. Further this study suggests to researchers that focus on internal and as well as external factors of SMEs in Pakistan. 
Corresponding author's email address: muhammadshahbazkhan7@gmail.com

Recommended citation: Khan, M. S. \& Siddiqui, S. H., (2019). SMEs Intention Towards Use and Adoption of Digital Financial Services. Sustainable Business and Society in Emerging Economies, 1(2), 65-80

DOI: $10.26710 /$ sbsee.v1i1.1007

\section{Introduction}

Small and medium enterprises are considered as engines of economic development and key contributors to economic activity, as a key-source of employment, growth, and invention (Rasheed et al., 2019). SMEs perform a significant role in the national financial system all over the world, providing employment, and contributing to innovation in the financial system which contribute significant efforts to achieve environmental sustainability and more inclusive growth in finance (Oecd, 2017). Access to finance for SMEs in emerging countries is one of core issue in development of SME sector as well as obstacle in economic growth.

Financial institutions at micro level are considered a good platform to enhance access to inclusive finance as well as laid-back access to finance and financial literacy for SMEs to support economic growth. Financial institution at micro level was initiated by Dr. Muhammad Younus in Bangladesh in 1984, and it became a developmental tool to alleviate poverty and promote entrepreneurship in developing areas (Mia, 2017). Financial institution is a key of financial service through digitalization that provides to SMEs who have no access to banks. The aim of financial institution at micro level is to provide money to poor people to invest in their business and to eliminate poverty among those people and contribute to the country's GDP and employment (Adjei \& Arun, 2009) but SMEs are unfortunately struggling due to lack of inclusive finance and financial literacy.

At global market inclusive finance, and digital financial services of SMEs to growth is a key constraint. Without access to finance many SMEs in global market fail and stagnate. At globally, nearly $90 \%$ of group have their own smart-phones, but $58 \%$ of group have access to the network connection with internet in addition to owning a mobile phone. According to Global Findex 2014 an estimated nearly 2 billion adults do not have access to a business transaction account and were unseen from the formalized financial system.

The World Bank Group with private and public sector combines determined to set a goal to attain Universal Financial Access (UFA) in 2020. The Universal Financial Access (UFA) aim to achieve about that in 2020 adults globally will be able to have access to a transaction account or digital instrument to store money, send and receive payments. Financial access is the first step toward broader inclusive finance, so that regardless of time and place peoples and firms can securely use of a range of right and proper financial services, including funds transfer and savings, payments, credit, and insurance.

The exponential growth of digitalization through mobile in the developing world has revolutionized the banking sector. Pakistan, with a population exceeding 180 million, has a high mobile phone penetration of $74 \%$ but $85 \%$ of the population is financially excluded and Banks use mobile technologies to deliver financial services to the unbanked poor, via mobile banking (m-banking) (Kemal, 2016).

SMEs in Pakistan are unfortunately struggling due to lack of inclusive finance and financial literacy and also among those struggling countries who are while growing their businesses focusing on the implementation and adoption of innovative systems. Current paper drives that how SMEs owners and managers in Pakistan trying to attain the aim of access to finance and intention towards use and adoption of digital financial services. The paper primarily discussed how digital financial services helping and improving SMEs owners and managers financial status which ultimately benefiting country economic health. 


\section{Problem Statement of the Study}

Access to finance is the main issue for emerging countries financial health and economy. Pervious research conducted to review about digital financial services through Micro-Finance Bank. This study highlighted that SMEs owners and managers intent towards use and adoption of digital financial services but due to lack of finance and awareness of unable to use digital financial services. Yet, In Pakistan unable to get desired results towards financial Inclusion. The digital financial services are opportunity for SMEs to adopt digital financial services and to cut their cost, increase their profitability and financial health. SMEs sectors are not fully aware and understand of the importance of digital financial services on SMEs development, and still in wait and see the stage in SMEs sectors development. Yet, In emerging countries, SMEs sectors owners and managers do not know and understand the strategic value of digital financial services for their business. The particular problem that I was presented in this research study was that in Pakistani SMEs owners and managers lacked knowhow of policies and plans, had no idea how to go about the intention and adoption of digital financial services.

\section{Research Gaps of the Study}

The research will fill a gap in the literature included theoretical, and contextual gaps on SMEs intention towards use and adoption of digital financial services. This study provides to SMEs intention towards use and adoption of digital financial services and to assist SMEs to achieve their goals to adopt of digital financial services and also to achieve maximize their performance. This research study discussed two research gaps theoretical and contextual gaps, which will fill gaps in the literature.

\section{Theoretical Gaps}

Many Researchers have been done research based on different theories. The researchers used these theories to determine the internal and external factors of SMEs. Previous studies focused more on external factors than internal factors of SMEs. This research study will focus on internal factors and for this purpose we added in this research, the theory of planned behavior (Ajzen, 1985) and the theory of technology acceptance model (Fred D. Davis et al., 1989), which, in this case, are the best theories to explain to the intention towards use and adoption of digital financial services. Some previous studies neglected to combine these two models, and the few that did, but different dimension of variables. These two theories will be merged to analyze the current phenomenon of SMEs intention towards use and adoption of digital financial services.

\section{Contextual Gaps}

Most of the research study has been conducted on SMEs intention towards use and adoption of digital financial services in developed countries. I have found very few research studies done in developing countries like Pakistan as some researchers did so but not dynamically. There is no research study to analyze SMEs intention towards use and adoption of digital financial services in South Punjab, Pakistan. This research works to analyze the problems of whether SMEs owner and manager intention towards use and adoption of digital financial services in Southern Punjab, Pakistan or not. This study will fill the research gap to explain the SMEs intention towards use and adoption of digital financial services of Southern Punjab, Pakistan.

\section{Research Objective}

RO1: To analyze the impact of SMEs owners and managers Attitudes towards Intention to Adopt of Digital Financial Services in South Punjab, Pakistan

RO2: To analyze the impact of SMEs owners and managers Subjective Norms towards Intention to Adopt of Digital Financial Services in South Punjab, Pakistan

RO3: To analyze the impact of SMEs owners and managers Perceived Behavior Control towards Intention to Adopt of Digital Financial Services in South Punjab, Pakistan

1.5 Research Questions

RQ 1: What is the impact of SMEs owners and managers Attitudes towards Intention to Adopt of Digital Financial Services in South Punjab, Pakistan? 
RQ 2: What is the impact of SMEs owners and managers Subjective Norms towards Intention to Adopt of Digital Financial Services in South Punjab, Pakistan?

RQ 3: What is the impact of SME owners and managers Perceived Behavior Control towards Intention to Adopt of Digital Financial Services in South Punjab, Pakistan?

\section{Scope of the Research Study}

This research has a broad scope in the future for persons of interest, especially the government, economists, NGOs, policy makers and SMEs managers and owners of Pakistan. This research paper would also be helpful for the SMEs owners and managers in South Punjab Pakistan for financial literacy and financial management decision and also for those industries at micro-level intention towards use and adoption of digital financial services.

\section{Literature Review}

\subsection{SMEs in Pakistan}

There is no single definition of SMEs. Its vary from country to country. According to SMEDA that SMEs a business entity in which employee size up to 250 persons and annual sales turnover is up to Rs.250 million. Small and medium enterprises can be total finances up to Rs.25 million. In Pakistan, SMEs (SMEDA) established in 1998. According to SMEDA SMEs constitute in Pakistan almost $90 \%$ of all the enterprises; employ $80 \%$ of the non-agricultural labor force; and their share in the annual GDP is $40 \%$, nearly while the share of SMEs in Global GDP is 55\%. The growth of small and medium sector is $8 \%$ in manufacturing sector, $10 \%$ in exports and $10 \%$ in service sector which need to be enhanced. There are more than 38 million small and medium enterprises in Pakistan wherein 8 lakhs are industrial units, 12 lakh service sector, 18 lakh commercial and retail shops and $41 \%$ of these industrial units are in urban areas and 59\% are set in rural areas (Pakistan Bureau of Statistics, 2019).

\subsection{Access to Finance for SMEs in Pakistan}

Financial institutions are considered a good platform to increase access to inclusive finance as well as easy access to finance and financial literacy for SMEs to boost economic growth but in Pakistan, to obtain these finances not easy for SMEs sectors. According to World Bank SMEs overall, nearly 70\% SMEs lack of access to credit in emerging markets. In Pakistan SMEs formalized financing through in the country, for the first time crossed the milestone of RS 500 billion and registered financing through bank at the end of economic year 2018 RS 513 billion and at the end of economic year 2017 financing recorded as RS 450 billion as shown 14\% growth (SBP Guidelines, 2019). The (SBP Guidelines, 2019) revealed in their reports that digital inclusive financial services market potential in Pakistan will cross US\$ 36 billion in 2025, contribute $7 \%$ enhancement to the GDP, will generate 4 million new jobs and result in US\$263 billion new credits.

\subsection{SMEs Intention towards Use and Adoption of Digital Financial Services}

Intention towards use and adoption involves mental actions such as planning and consideration towards digital financial services. SMEs Intention towards use and adoption towards digitalization transferring of products, buying, selling, services or exchanging information through the digitalization (Abbas, 2018). SMEs owner and managers intention towards use and adoption of digital financial services to enhance SMEs attractiveness in global markets. SMEs should be economically sound and well connected to markets by adopting digitalization technology. In a competitive and changing environment, SMEs have changed their way of working by updating the superiority of doing business so that they can compete in regional and global markets (Mukamanzi, 2018). SMEs in emerging countries intention towards use and adoption of digital financial services have less focus to compared developed countries. In undeveloped countries owners and managers of SMEs used the digital financial services to catch the attention of new customers, build a strong relationship with wholesalers, and minimize the cost of well-known customers (Seyal et al., n.d.). In Pakistan digital inclusive financial services market potential as per statistics will cross US $\$ 36$ billion by 2025, contribute 7\% enhancement to the GDP, 4 million new jobs providing and resulting in US\$ 263 billion new credits (SBP Guidelines, 2019). Many SMEs in Pakistan and individuals 
are able to improve their business and stay competitive through digital financial. However, mostly studies examined the intention towards use and adoption scale of individuals in context of SMEs. Yet, not enough research work created by academicians to examine SMEs intention towards use and adoption level in context of SMEs of Southern Punjab in Pakistan.

\subsection{SMEs Attitude towards Digital Financial Services}

An attitude to explain as "An individual's positive or negative point of view to performing the target performance (Ajzen, 1975). Many researchers argue that the significant positive impact of an attitude towards intention to adopt of digital financial services. To present their study (Fauzan, 2017) revealed that the positive strong attitude an organization on sustainability, and adoption of digitalization. In support of another researcher (Abbas et al., 2018) evaluated that the organizational factors, technological factors, and ecological factors had a direct significant impact on the intentions and adoption of digital financial services of the SMEs in Pakistan. These studies show that there is a trend to imitate the Pakistani SMEs who are successfully taken to avoid the risks of digitalization. Besides this, many researchers accomplish that SMEs an attitude towards intention to use and adoption does not lead to a significant impact on of digital financial services. (H. Zaied, 2012) they evaluated their study that insignificant impact of SMEs attitude towards adopting of digital financial services due to legal, risk, regulatory, and political barriers, and the least important barriers are social and cultural barriers (Riyadh et al., 2010). As difference studies show various results in the impact of attitude, this study will include the variable through a theory of technology acceptance model and thus, it is hypothesized tested in the context of SMEs in south Punjab, Pakistan.

H1 SMEs owners and managers attitude have influence on their intention towards use and adoption of digital financial services in South Punjab, Pakistan

\section{4. $\quad$ Perceived Usefulness}

Perceived usefulness define by (Fred D Davis \& Davis, 1989) as "the scale to which a person depend on a specifics system using would improve his or her job performance". Many scholars argue that the perceived usefulness have significant positive influence on intention towards use and adoption of digital financial services. To presented their study (Masocha, 2018) evaluated that a significant impact of perceived usefulness on digitalization. Another research argued that perceived usefulness (Intention towards use, training user, computer experience, system quality) have a significant impact on digitalization (Olumide, 2016). Besides this, many researchers accomplish that SMEs perceived usefulness on intention towards use and adoption insignificant impact on of digital financial services. Perceived usefulness determinant an attitudes theory of the technology acceptance model Thus, it is hypothesized tested in the context of SMEs of south Punjab in Pakistan.

H1.1 SMEs owners and managers perceived usefulness have influence on their intention towards use and adoption of digital financial services in South Punjab, Pakistan

\subsubsection{Perceived Ease of Use}

According to (Fred D. Davis MIS, 1989) defined perceived ease of use as "the scale to which a person perception a specific system that using would be free from effort". Perceived ease of use basic fundamental of the determinant of theory of technology acceptance model. It's referred in this study, to the belief that using digital financial services would be free of effort. Many researchers evaluated perceived usefulness have a significant impact on digitalization (Masocha, 2018) (Camilleri, 2018) (Kemal, 2016) (Olumide, 2016). Besides this, many researchers accomplish that SMEs perceived ease of use on intention towards use and adoption insignificant impact on of digital financial services. Perceived ease of use examine an attitudes theory of technology acceptance model and thus, it is hypothesized tested in the context SMEs of south Punjab in Pakistan.

H1.2 SMEs owners and managers perceived ease of use have influence on their intention towards use and adoption of digital financial services in South Punjab, Pakistan 


\subsection{SMEs Subjective Norms towards Digital Financial Services}

The subjective norms are additionally assumed to be a function of viewpoints, but ideas of a different kind, particularly the person's think that particular folks and organizations think he need to or have to not operate the behavior (Ajzen, 1985). Many researchers argue that the significant influence of subjective norms toward intention to use and adopt of digitalization. In the aid of evidence that SMEs managers and owners subjective norms toward intention towards use and adopt of digital services significant positive impact in the context of developing countries (Grandón \& Ramírez-Correa, 2018) (Uzoka et al., 2017). Besides this, many types of research accomplish that SMEs Subjective Norms towards intention to use and adoption does not lead to a significant impact on digital financial services (Khatimah \& Halim, 2016).As different studies show various results in the impact of Subjective norms, this study will include the variable through a theory of Planned behavior model and therefore, it is hypothesized tested in the context of SMEs of south Punjab in Pakistan.

H2 SMEs owners and managers subjective norms have influence on their intention towards use and adoption of digital financial services in South Punjab, Pakistan

\subsubsection{Normative Beliefs}

Normative beliefs (Tolma et al., 2006) define as contact on whether or not referent applicable groups approve of the action. Many researchers argue that have normative beliefs significant impact on intention towards use and adoption of digital financial services. Besides this, many types of research accomplish that SMEs normative beliefs towards intention to use and adoption does not lead to a significant impact on digital financial services. Normative beliefs determinant of Subjective norms taken from the theory of Planned behavior model and therefore, it is hypothesized tested in the context of SMEs of south Punjab in Pakistan.

H2.1 SMEs owners and managers opinion of referent to others have influence on their intention towards use and adoption of digital financial services in South Punjab, Pakistan

\subsubsection{Motivation to Comply}

As defines as by (Montano \& Kasprzyk, n.d) motivation to comply deal with the fact that humans can also or can also not fulfill with the social norms of the referent groups nearby the act. Many researchers argue that have a significant impact of motivation to comply on intention towards use and adoption of digital financial services. Besides this, many types of research accomplish that SMEs motivation to comply towards intention to use and adoption does not lead to a significant impact on digital financial services. Motivation to comply determinant of Subjective norms taken from the theory of Planned behavior modal and thus, it is hypothesized tested in the context of SMEs of south Punjab in Pakistan.

H2.2 SMEs owners and managers motivation to comply have influence on their intention towards use and adoption of digital financial services in South Punjab, Pakistan

\subsection{SMEs Perceived Behavior towards Digital Financial Services}

The research study $\mathrm{PBC}$ is the measurement of the perception study, which includes only internal influence. Many researchers argue that SMS owners and managers PBC have significant impact on intention towards use and adoption of digital financial services (Adeyinka, 2015) (Abbas, 2018).

Besides this, many types of research accomplish that SMEs perceived behavior towards intention to use and adoption does not lead to a significant impact on digital financial services. As difference studies show various results in the impact of Perceived Behavioral Control, this study will include the variable through a theory of Planned behavior model and therefore, it is hypothesized tested in the context of SMEs of south Punjab in Pakistan.

H 3: SMEs owners and managers perceived behavior have influence on their intention towards use and adoption of digital financial services in South Punjab, Pakistan 


\subsubsection{Control Beliefs}

As defined by Control beliefs (Netemeyer \& Ryn, 1991) relating to the feel of the opportunities, selfavailability of skills, and sources. Many researchers revealed in their find out about that control beliefs have a greater have an effects on intention towards use and adoption of digital financial services. Besides this, many types of research accomplish that SMEs control beliefs on intention towards use and adoption does not lead to a significant impact on digital financial services. Control beliefs determinant of perceived behavior control and adopting from theory of Planned behavior model and therefore, it is hypothesized tested in the context of SMEs of south Punjab in Pakistan.

H3.1 SMEs owners and managers control beliefs have influence on their intention towards use and adoption of digital financial services in South Punjab, Pakistan

\subsubsection{Perceived Power}

Perceived power defined by Ajzen (1991) relates to a person's assessment of the importance of these skills, resources, and possibilities for fulfillment of favored consequences. Many researchers argue that Perceived power has a greater influence on behavioral intention to use and adoption of digitalization. Besides this, many types of research accomplish that SMEs control beliefs towards intention to use and adoption does not lead to a significant impact on digital financial services. Perceived Power determinant of perceived behavior control taken from the theory of Planned behavior model and therefore, it is hypothesized tested in the context SMEs of south Punjab in Pakistan.

H3.2 SMEs owners and managers perceived power have influence on their intention towards use and adoption of digital financial services in South Punjab, Pakistan

\subsection{Theories of Consumer Behavior}

This research study discusses theories of consumer behavior that describe this research. Appropriate theories of consumer behavior will be used to test SMEs owners and managers' perception of intention towards use and adoption of digital financial services. In this study, we have applied the theory of planned behavior (Ajzen, 1985) and theory of technology acceptance model (Fred D. Davis et al., 1989). These models will be the basis of a new theoretical framework, further supported by using the reviewed of literature.

\subsubsection{Theory of Planned Behavior}

The TPB is proposed by (Ajzen, 1985). This TPB is the modified TRA (Ajzen, 1985). The TPB is the best concept to explain intention towards use and adoption. In this model of planned behavior intention measured by attitude, subjective norms and perceived behavioral control.

Source: (Ajzen, 1985)

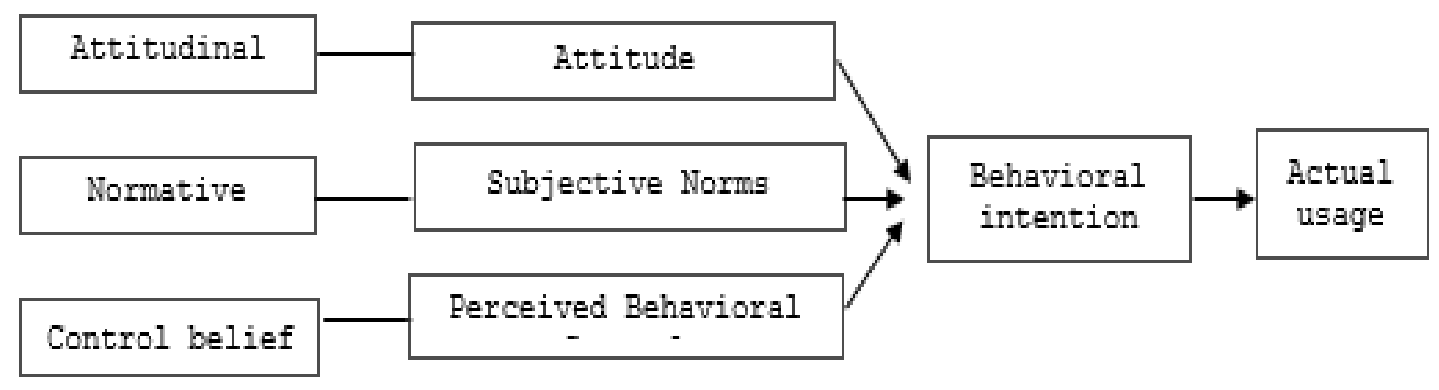

\subsubsection{Theory of Technology Acceptance Model}

(Fred D Davis, 1989) presented by the TAM model in their doctorate thesis. The TAM model an attitude is the modified by the TRA and TPB. The TAM model is the best theory to describe intention towards use and adoption of technology. In this TAM model intention measures by attitude of perceived usefulness and perceived ease of use (Fred D. Davis MIS, 1989); (Scherer et al., 2019); (Model et al., 1989).

Source: (Fred D. Davis MIS, 1989) 


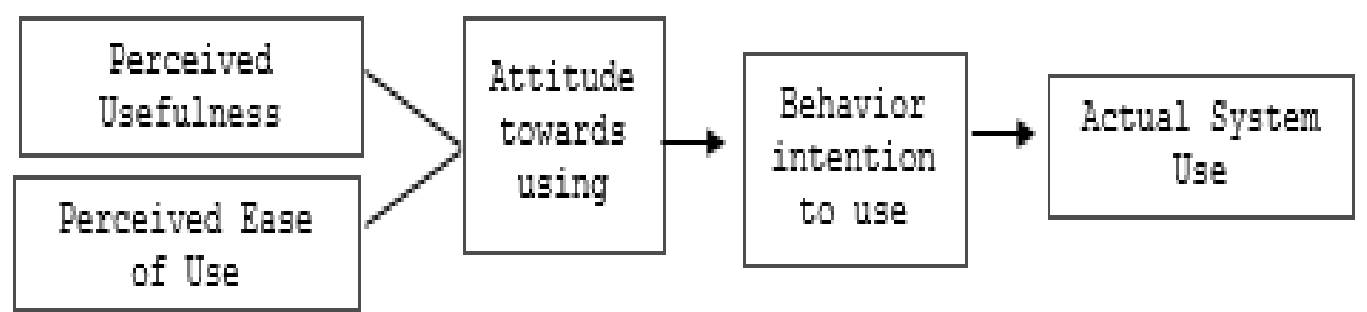

Perceived usefulness define as "the scale to which individual believes that the use of a specifics systems would increase his or her job performance" and Perceived ease of use defined as "the scale to which individual believes that the use of a specifics system would be free of effort (Fred D. Davis MIS, 1989).

\subsection{Proposed Research Model}

Current study proposed research framework is developed on the basis of theories of planned behavior and theory of technology acceptance model. The proposed model mixes of key variables of theory of planned behavior and theory of technology acceptance model.

\section{Proposed Research Model}

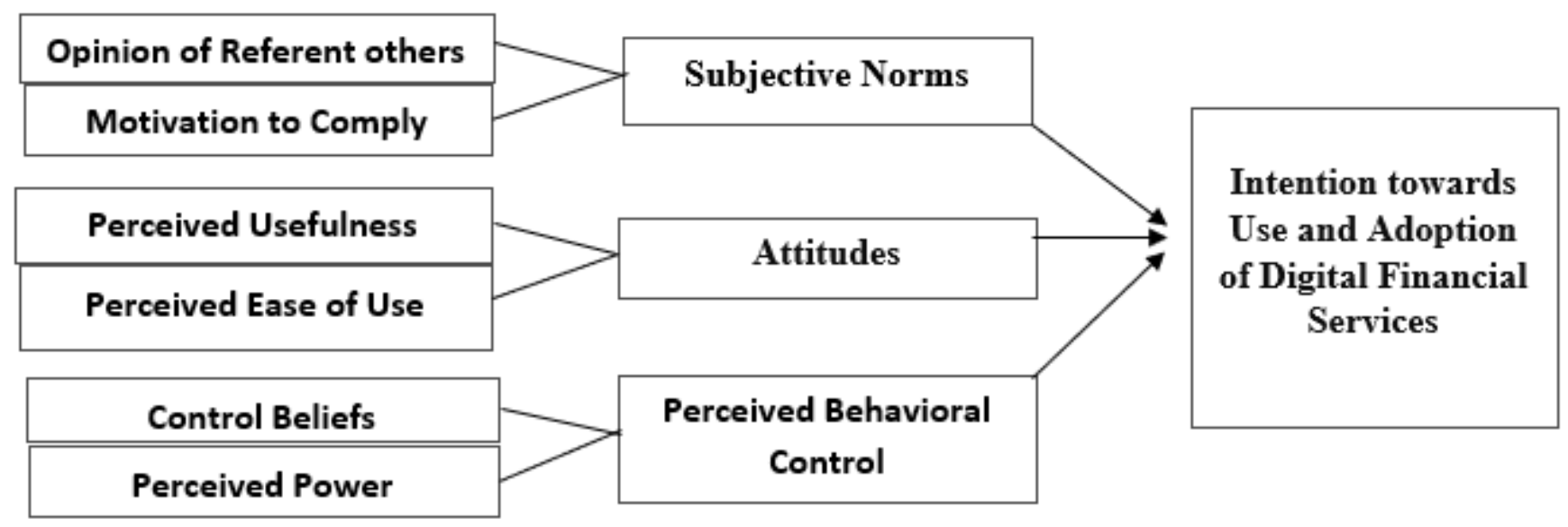

\section{Research Methodology}

\subsection{Research Design}

The causal research design being adopted to find out the SMEs owner and managers intention towards use and adoption of digital financial services. It is the study based on cause and effect of relationship among variables. Previous research study also adopts same pattern of research design.

\subsection{Research Survey Instrument}

The questionnaire used for this study was adapted and survey method has been applied to collect data in which closed ended questions were asked from concerned population. In questionnaire a five point Likert scale was used which includes 1 for strongly Disagree to 5 for strongly Agree.

\subsection{Research Analysis Techniques}

With the end goal of analyze of the data for this research descriptive inferential statistics, MS word, Excel and SPSS are used. The data was hardly collected from 232 out of 250 respondents because of very low response rate and putted that raw data into SPSS 20 to analyze it by correlation and regression statistical techniques. In this way the results of this research have been found. 


\subsection{Research Approach}

The nature of the research is quantitative which means the results of this endeavor will be quantified in numbers. SPSS IBM 20 will be used to run tests on the data.

\subsection{Sampling Technique and Size}

The data was obtained via online questionnaire survey drafted with the help of Google Docs. Respondents of various ages, genders, working in various SMEs of different nature in the South Punjab region were selected. The Data was obtained from 232 SMEs.

\subsection{Data analysis and Interpretation}

Data analysis and interpretations is being done via IBM SPSS Statistics 20.

\section{Data Analysis and Interpretation}

\subsection{Reliability Analysis}

The earliest step of test is to start with the reliability test of variables. Reliability test is run in study to make sure the consistency among different items of variables. In the given context, the stability of measure can be indicated by the reliability analysis. Different researchers use reliability analysis to check the consistency within the instrument. All the items of the instrument are included in the while conducting reliability test. To measure the reliability, value of Cronbach's alpha is generated. The maximum value of Cronbach's alpha is 1 . If the value of the reliability numeric of the instrument is closest to the 1 , that instrument will be considered a reliable instrument. The sig. value needs to lie between $(0.6-0.7)$, for reliability of the instrument to be accepted. If the values lie below 0.5 , the reliability will be poor and the need to make changes or rebuild the instrument from scratch will arise. The reliability test finds out the scale whether it provide exact measuring of the available data according to the study. Overall Cronbach's Alpha of all the 30 items was .910, which is more valid and acceptable and excellent. Thus the results show the data is significant and can be used for applying further tests of the study..

\begin{tabular}{|l|l|}
\hline \multicolumn{2}{|c|}{ Reliability Statistics } \\
\hline Cronbach's Alpha & No of Items \\
\hline .910 & 30 \\
\hline
\end{tabular}

\subsection{Normality Analysis}

The normality test applied to check whether the sample is laid under normal distribution or not. A statistical technique used to check whether a data collected from specific sample is normally distributed or not. The normality of the data can be checked by using mathematical techniques. A normality analysis is used to examine whether sample data has been drawn from a normally distributed population. A test named Shapiro-Wilk used to inspect the normality of data. Under this test, a null hypothesis developed to check that the data is normal distributed or not. This test tells us that if P-value of the data lies less than 0.05 that's means the acceptance of null hypothesis and vice versa..

\begin{tabular}{|l|l|l|l|l|l|l|}
\hline \multicolumn{7}{|c|}{ Tests of Normality } \\
\hline & \multicolumn{2}{|l|}{ Kolmogorov-Smirnova } & \multicolumn{3}{l|}{ Shapiro-Wilk } \\
\cline { 2 - 7 } & Statistic & Df & Sig. & Statistic & Df & Sig. \\
\hline Attitude & .172 & 232 & 000 & .873 & 232 & .000 \\
\hline Subjective Norms & .153 & 232 & .000 & .939 & 232 & .000 \\
\hline $\begin{array}{l}\text { Perceived Behavior } \\
\text { Control }\end{array}$ & .138 & 232 & .000 & .927 & 232 & .000 \\
\hline
\end{tabular}




\begin{tabular}{|l|l|l|l|l|l|l|}
\hline $\begin{array}{l}\text { Use of Intention } \\
\text { and }\end{array}$ & .160 & 232 & .000 & .901 & 232 & .000 \\
towards $\begin{array}{r}\text { Adoption } \\
\text { Digital }\end{array}$ & & & & & & \\
Financial Services
\end{tabular}

As in above table all values of the p-value (significant) is $<0.05$ which means that the data normal distributed and the null hypothesis will be accepted.

\subsection{Multicollinearity Analysis}

A multicollinearity test is a statistical tool to measure the strength of correlation, in the regression model among two or more variables, a multicollinearity test will be applied. The collinearity is good if lied between the independent variable to dependent variable. But there shouldn't the existence of collinearity among the variables of same nature as (collinearity among all independent variables/collinearity among all dependent variables). To check the collinearity, the tolerance value should be $>0.2$ and VIF should be $<5.0$.

\begin{tabular}{|l|l|l|l|}
\hline \multicolumn{3}{|c|}{ Coefficients' } \\
\hline \multicolumn{2}{|c|}{ Model } & Collinearity Statistics \\
\cline { 3 - 4 } \multicolumn{2}{|c|}{} & Tolerance & VIF \\
\hline \multirow{3}{*}{1} & Attitude & .780 & 1.282 \\
\cline { 2 - 4 } & Subjective Norms & .663 & 1.507 \\
\cline { 2 - 4 } & Perceived Behavior Control & .764 & 1.309 \\
\hline \multicolumn{3}{|l|}{ A. Dependent Variable: Intention towards Use and Adoption of Digital Financial Services } \\
\hline \multicolumn{2}{|l|}{} \\
\hline
\end{tabular}

Above the table of coefficients showed a result the tolerance value in above both of table is $>$ than 0.2 and $<$ less than 5 that meets aforementioned criteria. So the revealed that results show that there is no multicollinearity issue found among the variables of same nature.

\subsection{Regression Analysis}

In regression analysis is a statistical process for measuring the relationships among variables. It contains several techniques for demonstrating and analyzing numerous variables, when the emphasis is on the link between a dependent variable and one or more independent variables. So, test have been run to evaluate the attitude, subjective norms, and perceived behavior control intention towards use and adoption of digital financial services. The Regression Analysis is influenced to estimate the relationship between the dependent and independent variable. To analyze the effect of independent variables (Attitude, Subjective Norms and Perceived Behavior Control) on dependent variable (Intention towards use and adoption of Digital Financial Services), a bivariate regression test was run.

\begin{tabular}{|l|l|l|l|l|}
\hline \multicolumn{5}{|c|}{ Model Summary } \\
\hline Model & $\mathrm{R}$ & R Square & Adjusted R Square & $\begin{array}{l}\text { Std. Error of the } \\
\text { Estimate }\end{array}$ \\
\hline 1 & $.740 \mathrm{a}$ & .548 & .542 & 5.01193 \\
\hline A. Predictors: (Constant), Attitude, Subjective Norms and Perceived Behavior Control \\
\hline
\end{tabular}

Above table showed that the adjusted R2 measures adjusted for degree of freedom. In the above table, adjusted R2 value is .548 which is significant in this data. It shows that the SMEs owners and managers 
attitude, subjective norms and perceived behavior control explained 54.8\% variation in intention towards use and adoption of digital financial services.

\begin{tabular}{|l|l|l|l|l|l|l|}
\hline \multicolumn{2}{|l|}{ ANOVAa } \\
\hline \multirow{2}{*}{ Model } & $\begin{array}{l}\text { Sum } \\
\text { Squares }\end{array}$ & Df & Mean Square & F & Sig. \\
\hline \multirow{2}{*}{1} & Regression & 6948.337 & 3 & 2316.112 & 92.204 & $000 \mathrm{~b}$ \\
\cline { 2 - 7 } & Residual & 5727.232 & 228 & 25.119 & & \\
\cline { 2 - 6 } & Total & 12675.569 & 231 & & & \\
\hline
\end{tabular}

\begin{tabular}{|c|c|c|c|c|c|}
\hline \multicolumn{6}{|c|}{ Coefficientsa } \\
\hline \multirow[t]{2}{*}{ Model } & \multicolumn{2}{|c|}{$\begin{array}{l}\text { Unstandardized } \\
\text { Coefficients }\end{array}$} & \multirow{2}{*}{$\begin{array}{l}\text { Standardized } \\
\text { Coefficients } \\
\text { Beta }\end{array}$} & \multirow[t]{2}{*}{$\mathrm{t}$} & \multirow[t]{2}{*}{ Sig. } \\
\hline & $\mathrm{B}$ & $\begin{array}{l}\text { Std. } \\
\text { Error }\end{array}$ & & & \\
\hline (Constant) & 3.079 & 1.560 & & .974 & .050 \\
\hline Attitude & .624 & .093 & .340 & .748 & .000 \\
\hline Perceived Usefulness & .173 & .171 & .054 & .010 & .313 \\
\hline Perceived Ease of Use & 1.047 & .167 & .336 & .286 & .000 \\
\hline Subjective Norms & .657 & .099 & .363 & .641 & .000 \\
\hline $\begin{array}{l}\text { Opinion of Referent } \\
\text { others }\end{array}$ & .542 & .179 & .169 & .036 & .003 \\
\hline Motivation to comply & .768 & .168 & .249 & .577 & .000 \\
\hline $\begin{array}{l}\text { Perceived Behavior } \\
\text { Control }\end{array}$ & .468 & .100 & .237 & .662 & .000 \\
\hline Control Beliefs & .310 & .173 & .096 & .790 & .075 \\
\hline Perceived Power & .612 & .192 & .170 & .193 & .002 \\
\hline
\end{tabular}

As shown above table SMEs owners and managers attitude has a positive strong significant impact on intention towards use and adoption of digital financial services, with $\beta=0.340$ and $\mathrm{P}$ less than $<0.05$. The regression coefficient table exhibits that the $\mathrm{P}<0.05$. Hence, first hypothesis $(\mathrm{H} 1)$ is approved and above results reveal that SMEs owners and managers attitude roughly contributes $34.0 \%$ to intention towards use and adoption of digital financial services. Sub variables of attitude is perceived usefulness insignificant impact on intention towards use and adoption of digital financial services, with $\beta=0.054$ and $\mathrm{P}$ less than $>0.05$. The regression coefficient table exhibits that the $\mathrm{P}>0.05$. Hence, first sub hypothesis (H1.1) is rejected and above results reveal that SMEs owners and managers attitude roughly contributes $5.4 \%$ to intention towards use and adoption of digital financial services. Second sub variables of attitude is perceived ease of use has significant impact on intention towards use and adoption of digital financial services, with $\beta=0.336$ and $\mathrm{P}$ less than $<0.05$. The regression coefficient table exhibits that the $\mathrm{P}<0.05$. Hence, hypothesis (H1.2) is approved and above results reveal that SMEs owners and managers attitude roughly contributes $33.6 \%$ to intention towards use and adoption of digital financial services.

Subjective norms has significant impact on intention towards use and adoption of digital financial services, with $\beta=0.363$ and $\mathrm{P}$ less than $<0.05$. The regression coefficient table exhibits that the $\mathrm{P}<0.05$. Hence, hypothesis (H2) is approved and above results reveal that SMEs owners and managers attitude 
roughly contributes $36.3 \%$ to intention towards use and adoption of digital financial services. Sub variables of SBN is Opinion of referent others with $\beta=0.169$ and motivation to comply with $\beta=0.249$ and $\mathrm{P}$ less than $<0.05$. Hence, hypothesis ( $\mathrm{H} 2.1$ and 2.2) is approved and above results reveal that SMEs owners and managers attitude roughly contributes $16.9 \%$ and $24.9 \%$ to intention towards use and adoption of digital financial services.

Perceived behavior control has significant impact on intention towards use and adoption of digital financial services, with $\beta=0.237$ and $P$ less than $<0.05$. The regression coefficient table exhibits that the $P$ $<0.05$. Hence, hypothesis $(\mathrm{H} 3)$ is approved and above results reveal that SMEs owners and managers attitude roughly contributes $23.7 \%$ to intention towards use and adoption of digital financial services. Sub variables of PBC is Control Beleifs with $\beta=0.096$ and Perceived Power with $\beta=0.170$ and $P$ value of $C B$ is greater than $>0.05$ and $\mathrm{PP}$ less the $\mathrm{P}<0.005$. Hence, hypothesis $\mathrm{H} 3.1$ rejected and 3.2 is approved and above results reveal that SMEs owners and managers attitude roughly contributes $9.6 \%$ and $17.0 \%$ to intention towards use and adoption of digital financial services.

\subsection{Correlation Analysis}

This test helps to figure out the extent of relationships among different variables of the research. It tells about intensity and direction (positive or negative) of the relation. The values to check the relationship are ranges from -1 to +1 that show the direction of relationship, whether the relationship is positive or negative.

\begin{tabular}{|c|c|c|c|c|c|}
\hline \multicolumn{6}{|c|}{ Correlations } \\
\hline & & Attitude & $\begin{array}{l}\text { Perceived } \\
\text { Use } \\
\text { Fullness }\end{array}$ & $\begin{array}{l}\text { Perceived } \\
\text { Ease of } \\
\text { Use }\end{array}$ & $\begin{array}{l}\text { Use of } \\
\text { Intention and } \\
\text { Adoption } \\
\text { towards } \\
\text { Digital } \\
\text { Financial } \\
\text { Services }\end{array}$ \\
\hline \multirow[t]{3}{*}{ Attitude } & $\begin{array}{l}\text { Pearson } \\
\text { Correlation }\end{array}$ & 1 & $.857 * *$ & $.868 * *$ & $.579 * *$ \\
\hline & Sig. (2-tailed) & & .000 & .000 & .000 \\
\hline & $\mathrm{N}$ & 232 & 232 & 232 & 232 \\
\hline \multirow[t]{3}{*}{ Perceived Use Fullness } & $\begin{array}{l}\text { Pearson } \\
\text { Correlation }\end{array}$ & $.857 * *$ & 1 & $.488 * *$ & $.413 * *$ \\
\hline & Sig. (2-tailed) & .000 & & .000 & .000 \\
\hline & $\mathrm{N}$ & 232 & 232 & 232 & 232 \\
\hline \multirow[t]{3}{*}{ Perceived Ease of Use } & $\begin{array}{l}\text { Pearson } \\
\text { Correlation }\end{array}$ & $.868 * *$ & $.488 * *$ & 1 & $.583 * *$ \\
\hline & Sig. (2-tailed) & .000 & .000 & & .000 \\
\hline & $\mathrm{N}$ & 232 & 232 & 232 & 232 \\
\hline \multirow{3}{*}{$\begin{array}{l}\text { Use of Intention and } \\
\text { Adoption towards Digital } \\
\text { Financial Services }\end{array}$} & $\begin{array}{l}\text { Pearson } \\
\text { Correlation }\end{array}$ & $.579 * *$ & $.413 * *$ & $.583 * *$ & 1 \\
\hline & Sig. (2-tailed) & .000 & .000 & .000 & \\
\hline & $\mathrm{N}$ & 232 & 232 & 232 & 232 \\
\hline
\end{tabular}

As the above table of correlation showed a result that the relationship between SMEs owners and managers attitude on their intention towards use and adoption of digital financial services is moderate significant but positive with the $\mathrm{r}$ value $.579^{* *}$ and the relationship between SMEs owners and managers 
perceived usefulness on their intention towards use and adoption of digital financial services is weak significant but positive with the $\mathrm{r} 0.413^{* *}$. Further above table showed that the relationship between SMEs owners and managers perceived ease of use on their intention towards and adoption of digital financial services is moderate significant but positive with the $\mathrm{r} 0.583^{* *}$.

\begin{tabular}{|c|c|c|c|c|c|}
\hline \multicolumn{6}{|c|}{ Correlations } \\
\hline & & $\begin{array}{l}\text { Subjective } \\
\text { Norms }\end{array}$ & $\begin{array}{l}\text { Opinion } \\
\text { of } \\
\text { Referent } \\
\text { Ohers }\end{array}$ & $\begin{array}{l}\text { Motivation } \\
\text { to comply }\end{array}$ & $\begin{array}{l}\text { Use of } \\
\text { Intention } \\
\text { and } \\
\text { Adoption } \\
\text { towards } \\
\text { Digital } \\
\text { Financial } \\
\text { Services }\end{array}$ \\
\hline \multirow[t]{3}{*}{ Subjective Norms } & $\begin{array}{l}\text { Pearson } \\
\text { Correlation }\end{array}$ & 1 & $.864 * *$ & $.875^{* *}$ & $.632 * *$ \\
\hline & Sig. (2-tailed) & & .000 & .000 & .000 \\
\hline & $\mathrm{N}$ & 232 & 232 & 232 & 232 \\
\hline \multirow[t]{3}{*}{$\begin{array}{l}\text { Opinion of Referent } \\
\text { Ohers }\end{array}$} & $\begin{array}{l}\text { Pearson } \\
\text { Correlation }\end{array}$ & $.864 * *$ & 1 & $.512 * *$ & $.546 * *$ \\
\hline & Sig. (2-tailed) & .000 & & .000 & .000 \\
\hline & $\mathrm{N}$ & 232 & 232 & 232 & 232 \\
\hline \multirow[t]{3}{*}{ Motivation to comply } & $\begin{array}{l}\text { Pearson } \\
\text { Correlation }\end{array}$ & $.875 * *$ & $.512 * *$ & 1 & $.553 * *$ \\
\hline & Sig. (2-tailed) & .000 & .000 & & .000 \\
\hline & $\mathrm{N}$ & 232 & 232 & 232 & 232 \\
\hline \multirow{3}{*}{$\begin{array}{lr}\text { Use of } & \text { Intention and } \\
\text { Adoption } & \text { towards } \\
\text { Digital } & \text { Financial } \\
\text { Services } & \end{array}$} & $\begin{array}{l}\text { Pearson } \\
\text { Correlation }\end{array}$ & $.632 * *$ & $.546 * *$ & $.553 * *$ & 1 \\
\hline & Sig. (2-tailed) & .000 & .000 & .000 & \\
\hline & $\mathrm{N}$ & 232 & 232 & 232 & 232 \\
\hline
\end{tabular}

As the above table of correlation showed a result that the relationship between SMEs owners and managers subjective norms on their intention towards use and adoption of digital financial is positively strong significant with the $\mathrm{r} 0.632 * *$ and the relationship between SMEs owners and managers opinion of referent to others on their intention towards use and adoption of digital financial services is moderate significant but positive with the $\mathrm{r} 0.546^{* *}$. Further above table showed that the relationship between SMEs owners and managers motivation to comply have influence on their intention towards use and adoption of digital financial services is moderate significant but positive with the $\mathrm{r} 0.553^{* *}$.

\begin{tabular}{|l|l|l|l|l|l|}
\hline \multicolumn{2}{|c|}{ Correlations } \\
\hline & $\begin{array}{l}\text { Perceived } \\
\text { Behavior } \\
\text { Control } \\
\text { Control } \\
\text { Beliefs }\end{array}$ & $\begin{array}{l}\text { Perceived } \\
\text { Power }\end{array}$ & $\begin{array}{l}\text { Use } \\
\text { Intention } \\
\text { and } \\
\text { Adoption } \\
\text { towards } \\
\text { Digital } \\
\text { Financial } \\
\text { services }\end{array}$ \\
\hline $\begin{array}{l}\text { Perceived } \\
\text { Behavior Control }\end{array}$ & $\begin{array}{l}\text { Pearson } \\
\text { Correlation }\end{array}$ & 1 & & & \\
$.513^{* *}$ \\
\hline
\end{tabular}




\begin{tabular}{|c|c|c|c|c|c|}
\hline & Sig. (2-tailed) & & .000 & .000 & .000 \\
\hline & $\mathrm{N}$ & 232 & 232 & 232 & 232 \\
\hline \multirow[t]{3}{*}{ Control Beliefs } & $\begin{array}{l}\text { Pearson } \\
\text { Correlation }\end{array}$ & $.876^{* *}$ & 1 & $.477 * *$ & $.412 * *$ \\
\hline & Sig. (2-tailed) & .000 & & .000 & .000 \\
\hline & $\mathrm{N}$ & 232 & 232 & 232 & 232 \\
\hline \multirow[t]{3}{*}{ Perceived Power } & $\begin{array}{l}\text { Pearson } \\
\text { Correlation }\end{array}$ & $.842 * *$ & $.477 * *$ & 1 & $.474 * *$ \\
\hline & Sig. (2-tailed) & .000 & .000 & & .000 \\
\hline & $\mathrm{N}$ & 232 & 232 & 232 & 232 \\
\hline \multirow{3}{*}{$\begin{array}{l}\text { Use of Intention } \\
\text { and Adoption } \\
\text { towards Digital } \\
\text { Financial } \\
\text { Services }\end{array}$} & $\begin{array}{l}\text { Pearson } \\
\text { Correlation }\end{array}$ & $.513 * *$ & $.412 * *$ & $.474 * *$ & 1 \\
\hline & Sig. (2-tailed) & .000 & .000 & .000 & \\
\hline & $\mathrm{N}$ & 232 & 232 & 232 & 232 \\
\hline
\end{tabular}

As the above table of correlation showed a result that the relationship between SMEs owners and managers perceived behavior on their intention towards use and adoption of digital financial services is moderate significant but positive with the $\mathrm{r}$ value $0.513^{* *}$ and further the relationship between SMEs owners and managers control beliefs on their intention towards use and adoption of digital financial services is weak significant but positive with the $\mathrm{r}$ value $0.412 * *$. Further above table showed that the relationship between SMEs owners and managers perceived power have influence on their intention towards use and adoption of digital financial services is weak significant but positive with the $r$ value $0.474 * *$.

\section{Conclusion}

This study measuring the SMEs owners and managers' intention towards use and adoption of digital financial services. The Sample size collected from SME's owners and managers 232 was collected in Southern Punjab, Pakistan. This study overall Cronbach's Alpha of all the items was more valid and acceptable and excellent. Thus the results show the data is significant and can be used for applying further tests of the study. All the data of variables items is normality distributed because shapiro-wilk table all values of the p-value (significant) is $<0.05$ and It' means that the null hypothesis will be accepted. The coefficients showed a result the tolerance value in above both of table is > than 0.2 and < less than 5 that meet the criteria. So the revealed that results show that there is no multicollinearity issue found among the variables of same nature. Finally, concluded that the SMEs owners and managers attitude, subjective norms, perceived behavior control have positively correlated with intention towards use and adoption of digital financial services and accepted the null hypothesis.

\section{Future Recommendations and Implication}

This study provides future works to future researchers to adopt new version of model that the theory of extended technology acceptance model and others. Further recommended that focus on overall SMEs in Pakistan on internal and as well as external factors of SMEs. The research scholar in future to take into consideration of Secondary data for research in their studies, which provide extra knowledge about of the SMEs owners and managers. The Government, SMEDA and SMEs Bank desires to take determines for the expansion, and development of the SME sector of Pakistan, which can perform significant role in socio- economic development of the country. Further, they should create awareness program, training, technical institution and make a rules and regulation. The Government of Pakistan should be providing access to Finance for SMEs owners and managers intend to use and adoption latest technology for the 
purpose of cut their cost, increase their profitability and financial health and also contribution in exports of Pakistan.

\section{Limitation of the Study}

This research was only limited to the in South Punjab, Pakistan hence the results cannot be generalized. This research covers only internal problems that arise in SMEs and how it affects their owners, manager decision. In this research work, with a limited data 232 of sample size is collected, which is not the acceptable representation of conducting this economic rationale research in a more dynamic way. The sampling method of random sampling method can also be considered a possible limitation because the respondent we are choosing on random basis may not be reliable. So in future other sampling methods should be chosen which can represent the whole population. Due to time limitation we conducted this study only in South Punjab.

\section{References}

Abbas, A. (2018). Affecting Factors to Intentions to Adoption of E-Commerce Technologies in SMEs of Pakistan. The Journal of Social Sciences Research, SPI4, 147-155. https://doi.org/10.32861/jssr.spi4.147.155

Abbas, A., Abdullah, S. H., \& Saad, R. M. (2018). Affecting factors to intentions to adoption of ECommerce Technologies in SMEs of Pakistan. Journal of Social Sciences Research, 2018(Special Issue 4), 147-155. https://doi.org/10.32861/jssr.spi4.147.155

Adeyinka, T. (2015). Predicting Users' Continuance Intention Toward E-payment System : An Extension of the Technology Acceptance Model. July. https://doi.org/10.4018/ijissc.2014010104

Adjei, J. K., \& Arun, T. (2009). Poverty Reduction: The Case of Sinapi Aba Trust of Ghana March 2009 BWPI Working Paper 87. March, 1-23.

Ajzen, I. (1975). Attitude Theory and Measurement. In Belief, attitude, intention, and behavior: An introduction to theory and research. Reading, MA: Addison.Wesley (p. 33).

Ajzen, I. (1985a). Copyright at UMD. Action-Control: From Cognition to Behavior, 11-39.

Ajzen, I. (1985b). From Intentions to Actions: A Theory of Planned Behavior. Action Control, 11-39. https://doi.org/10.1007/978-3-642-69746-3_2

Camilleri, M. (2018). The SMEs' Technology Acceptance of Digital Media for Stakeholder Engagement. August. https://doi.org/10.1108/JSBED-02-2018-0042

Davis, F D. (1986). A technology acceptance model for empirically testing new end-user information systems: Theory and results. Unpublished Doctoral Dissertation, MIT Sloan School of Management, Cambridge, M.A, Ph.D.(May), 291. https://doi.org/oclc/56932490

Davis, Fred D., Bagozzi, R. P., \& Warshaw, P. R. (1989). User Acceptance of Computer Technology: A Comparison of Two Theoretical Models. Management Science, 35(8), 982-1003. https://doi.org/10.1287/mnsc.35.8.982

Davis, Fred D, \& Davis, B. F. D. (1989). Perceived Usefulness , Perceived Ease of Use , and User Acceptance of Information Technology. 13(3), 319-340.

Fauzan, M. (2017). Attitude towards adoption of sustainable technology by Malaysian SMEs and its impact on organizational performance Faculty of Business , Government \& Law University of Canberra September 2017. September.

Fred D. Davis MIS. (1989). Perceived Usefulness, Perceived Ease of Use, and User Acceptance of Information Technology. MIS Quarterly, https://doi.org/10.1016/j.cell.2017.08.036

Grandón, E. E., \& Ramírez-Correa, P. (2018). Managers/owners' innovativeness and electronic commerce acceptance in chilean smes: A multi-group analysis based on a structural equation model. Journal of Theoretical and Applied Electronic Commerce Research, 13(3), 1-16. https://doi.org/10.4067/S0718-18762018000300102

Guidelines, G. (2019). Digital Financial Services ( DFS ) - Innovation Challenge Facility State Bank of Pakistan. April.

H. Zaied, A. N. (2012). Barriers to E-Commerce Adoption in Egyptian SMEs. International Journal of 
Information Engineering and Electronic Business, 4(3), 9-18. https://doi.org/10.5815/ijieeb.2012.03.02

Kemal, A. A. (2016). Mobile Banking for Financial Inclusion in Pakistan. June 2015.

Khatimah, H., \& Halim, F. (2016). The effect of attitude and its decomposed, subjective norm and it decomposed on intention. Journal of Scientific Research and Development, 3(1), 21-36.

Masocha, R. (2018). Adoption of Mobile Money Services and the Performance of Small and Medium Enterprises in Zimbabwe. Academy of Accounting and Financial Studies Journal, 22(3), 1-11.

Mia, A. (2017). An Overview of the Microfinance Sector in Bangladesh An Overview of the Microfinance Sector in Bangladesh. 7(May). https://doi.org/10.13106/eajbm.2017.vol7.no2.31

Model, T. A., Davis, F., \& Action, R. (1989). 410 • A very heavily cited paper. 1986.

Mukamanzi, F. (2018). East Africa Collaborative Ph . D . Program in Economics and Management East Africa Research Papers in Business, Entrepreneurship and Management The effects of ICT adoption on Small and Medium sized enterprises in Rwanda : A Case study of Kigali City East.

Netemeyer, R., \& Ryn, M. Van. (1991). The Theory of Planned Behavior.

Oecd. (2017). Enhancing the Contributions of SMEs in a Global and Digitalised Economy. Oecd, June, 7-8. https://www.oecd.org/mcm/documents/C-MIN-2017-8-EN.pdf

Olumide, O. D. (2016). Technology Acceptance Model as a predictor of using information system' to acquire information literacy skills. Library Philosophy and Practice (e-Journal), November, 1-27. https://doi.org/10.1016/j.ygyno.2014.12.020

Rasheed, R., Siddiqui, S. H., Mahmood, I., \& Khan, S. N. (2019). Financial Inclusion for SMEs: Role of Digital Micro-financial Services. Review of Economics and Development Studies, 5(3), 429-439. https://doi.org/10.26710/reads.v5i3.686

Riyadh, A. N., Bunker, D., \& Rabhi, F. (2010). Barriers to E-Finance Adoption in Small and Medium Sized Enterprises (SMEs) in Bangladesh. Ssrn, 1. https://doi.org/10.2139/ssrn.1726262

Scherer, R., Siddiq, F., \& Tondeur, J. (2019). The technology acceptance model (TAM): A meta-analytic structural equation modeling approach to explaining teachers' adoption of digital technology in education. Computers and Education, 128(0317), 13-35. https://doi.org/10.1016/j.compedu.2018.09.009

Seyal, A. H., Awais, M. M., Shamail, S., \& Abbas, A. (n.d.). Determinants of Electronic Commerce in Pakistan: Preliminary Evidence from Small and Medium Enterprises Determinants of Electronic Commerce in Pakistan: Preliminary Evidence from Small. November 2014, 37-41. https://doi.org/10.1080/10196780412331311801

Tolma, E. L., Reininger, B. M., Evans, A., \& Ureda, J. (2006). Examining the theory of planned behavior and the construct of self-efficacy to predict mammography intention. Health Education and Behavior, 33(2), 233-251. https://doi.org/10.1177/1090198105277393

Uzoka, F.-M. E., Shemi, A. P., \& Seleka, G. G. (2017). Behavioral Influences on E-Commerce Adoption in a Developing Country Context. The Electronic Journal of Information Systems in Developing Countries, 31(1), 1-15. https://doi.org/10.1002/j.1681-4835.2007.tb00213.x 